\title{
BANNING, BLOCKING AND BOOSTING: TWITTER'S SOLO-REGULATION OF EXPRESSION
}

\section{Marko Milosavljević :: Sally Broughton Micova}

IZVORNI ZNANSTVENI RAD / DOI: 10.20901/ms.7.13.3 / PRIMLJENO: 30.10.2015.

ABSTRACT The regulation or self-regulation of online media is one of the key dilemmas of contemporary digital media and policy environment. This includes the new digital intermediary gatekeepers such as social media. The private rules of intermediaries, such as their 'terms of service' and content policies, importantly define their functioning and are sometimes thought of as self-regulatory mechanisms. Online intermediaries are increasingly being called upon to engage in codes of conduct or decisions about content. We focus on Twitter as one of the largest and most relevant new gatekeepers because of its use as source of news. The terms and other documents of Twitter are analysed as tools of self-regulation, and as the context within which the individual users and mass media (must) function in today's digital environment. We also look at how Twitter has applied this framework in two high profile cases.

\section{KEY WORDS}

GATEKEEPERS, SOCIAL MEDIA, TWITTER, SELF-REGULATION, SELF-REGULATORY FRAMEWORK, SOLO-REGULATION, DIGITAL MEDIA

Authors note

Marko Milosavljević :: University of Ljubljana, Faculty of Social Sciences, Slovenia :: marko.milosavljevic@fdv.uni-lj.si

Sally Broughton Micova :: University of East Anglia, School of Politics, Philosophy, Language and Communication Studies, UK :: s.broughton-micova@uea.ac.uk 


\section{INTRODUCTION}

Self-regulation has long been a part of media regulation frameworks in Western societies for 'traditional' media. The assumed power of the media and the need to balance media freedoms with other rights necessitated some regulation, but its importance as a vehicle for expression and watchdog of governmental power, has meant self-regulation has usually been preferred. One way the function of media has been conceived is as gatekeeping (White, 1950; Tuchman, 1978; Gans, 1979), in which distribution and selection are defining activities. In traditional media, one can see that where there has been a stronger gatekeeping role, such as in the few holders of limited broadcast frequencies pushing content to audiences, states have tended more towards regulation; whereas for media with less gatekeeping power, such as the print press, there has been more reliance on self-regulation.

There is renewed interest in the concept of gatekeeping that applies it to new Internetbased media, from the production perspective, particularly in relation between users/ consumers and traditional media professionals/producers (Livingstone et al., 2003) and from the distribution perspective, due to new issues related to digital distribution and gateways (Enli, 2007; Ristow, 2013). As more people use social media and online platforms, such as Twitter, for news and information access, they now represent important gatekeepers in terms of their market power and their role in how users access media content.

Twitter is at the forefront of a fundamental change in how people consume media and journalism, as many now arrive at news through social media and search engines, rather than through the home pages or broadcast and print editions of news media. Twitter is also a key social media platform for news content production (Mitchell et al., 2012), as a tool (Vis, 2013), source (Milosavljević, 2014) and beat (Broersma and Graham, 2013) for journalists and other media professionals. As Adrienne Lafrance and Robinson Meyer wrote in a recent commentary in The Atlantic, the attention on a platform "that's not that widely used may feel outsized, but that's because its influence on publishing is gigantic", and Twitter as a publishing platform "might be seen as a microcosm for the powershift in media from traditional gatekeepers to the rest of us" (Lafrance and Meyer, 2014). This makes it a powerful example of the new kind of gatekeeper.

Research and policy are lagging behind the development of technology, and thus the regulatory framework for these gatekeepers and their distributing and selecting activities has not been fully established. There were relatively early calls for regulating "new forms of media concentration including legacy media, new media and search engines" (Schulz, 2008: 73), and calls for "monitoring of new elements that are not relevant to the existing legal and regulatory framework for media plurality, but are relevant to the objectives that lie behind these instruments" (Labo and Tambini, 2015). In spite of this, there are only sporadic policy measures that "do not amount to a coherent basis for on-going assessment of the need for regulatory oversight of whether the strategies of gatekeepers are inconsistent with public values" (Mansell, 2014). Measures referred to as 'self-regulation', as yet are the default option for dealing with new gatekeepers in terms 
of content. However, social media like Twitter lack the editorial teams of traditional media, have business models based on "lock in" and other network effect, and do not come from that tradition in which the public interest is a recognised and valued concept. This has lead two successive UN Special Rapporteurs on Freedom of Expression to voice concern about the transfer of regulatory responsibilities to these private companies (United Nations, 2011, 2016), and freedom of speech organisations such as Article 19 to warn against the privatisation of censorship (Article 19, 2013).

This paper focuses on Twitter as a new gatekeeper. It examines its policies and terms as a form of self-regulatory framework and then looks at how this framework has been applied in two high profile cases. It argues that Twitter's internal policies and arrangements with its users should not be uncritically accepted as self-regulatory mechanisms, and may be more appropriately defined as solo-regulation. It also argues that there is a need for social media companies to work together, and with their users, on fair and transparent self-regulatory frameworks.

\section{THEORETICAL FRAMEWORK}

\section{The media as 'gatekeepers'}

The concept of gatekeeping (White, 1950; Breed, 1955; Tuchman, 1978; Gans, 1979) has been used to describe the role of mass media for a long time. It refers to selections that are made in media work, especially decisions about whether or not to admit the story through the gates of news medium into the news channels (McQuail, 1994: 213). Pamela Shoemaker et al. (2001) defined it as the process by which "billions of messages that are available in the world get cut down and transformed into the hundreds of messages that reach a given person on a given day". The acts of gatekeeping are selective and distributive. As Graeff Erhardt et al. (2014) describe, they can be displaying and repeating, or withholding or deleting.

Social media and online platforms, such as Twitter, fall within the description of online gatekeepers as defined by Bill Ristow (2013), which include the hosting companies that house the websites of individual users, the Internet Service Providers (ISPs) that provide connection to the Internet, the search engines and social media platforms. These gatekeepers, particularly social media, are becoming increasingly relevant in terms of income and economic strength, in terms of users' spending time and other habits, in politics ${ }^{1}$, and as a pathway to news.

The Internet emerged as a 'free' social space in which there was no place or need for government intervention (Lievens and Valcke, 2013). With low barriers to entry, or limits on who or how many could 'broadcast', the early impressions were that the multitude of

\footnotetext{
${ }^{1}$ In a resolution entitled "On journalism and new media - creating a public sphere in Europe", a majority of Members of the European Parliament agreed that: "Social media are particularly adequate for communication: Social media can reach new audiences who have no interest in conventional media channels. These audiences expect not only to have access to media but to respond to it, share and use information. To reach these audiences, one must be where the conversation takes place, i.e. Facebook, Twitter and other online social networks." (Løkkegaard, 2010)
} 
channels and content might do away with the need for regulation (Lees et al., 2000), as if the gates had been open. However, research has showed that "contrary to the claims that old media gatekeepers have been eliminated, gates and gatekeepers are still a critical part of the information landscape" (Karpinnen, 2013: 114). In what Robin Mansell (2014) has called "platformisation", these online media, or platforms, "influence which ideas citizens are able to find easily and whether it will even be possible to conceive of a public sphere for democratic dialogue in the future".

Research into the role of these new gatekeepers, including Twitter is still nascent. From a content perspective, there has been research on Twitter as a gatekeeper of news values (Diakopoulos and Zubiaga, 2014), and as a shaper of political debates through hashtags (Bastos et al., 2013) and through acting as proxy for public opinion to mainstream media (Anstead and O'loughlin, 2011, 2014). Recent work from a media pluralism perspective has established the term "information intermediaries" to refer to search and social media platforms (Tambini and Labo, 2016; Moore, 2016), also emphasizing their gatekeeping role. There has been also some research in certain aspects of the wider self-regulatory framework of the new gatekeepers (Ristow, 2013; MacKinnon et al., 2014). There is mounting evidence that platforms such as Twitter are influential gatekeepers in terms of public discourse, and that they are increasingly dominant in the market in a way that old media rarely, if ever, achieved. At the same time, self-regulation seems to be the default mode for dealing with content and services online ${ }^{2}$.

\section{Self-regulation in the media}

Self-regulation happens when the industry or profession is regulating, instead of a government, and in the media it is more commonly done by companies working collectively, often to stave off government regulation (Campbell, 1999). In the process of self-regulation, "rules that govern market behaviour are developed and enforced by the governed, themselves" (Latzer et al., 2013: 376). Its recognized advantages are that it can be flexible, done at low-costs to government, and make use of the technical knowledge of the industry. However, as Angela J. Campbell's (1999) extensive study of a broad range of self-regulatory mechanisms set up for various types of media found, failures are common, and there are certain factors for success. She concluded that success of self-regulation depended upon industry having incentives to participate, the ability of government to regulate as a fall back option, and the use of clear and measurable standards rather than subjective ones. Both scholars and human rights advocates have argued that selfregulatory mechanisms in the field of media must be open to public participation and allow for some form of appeal on decisions made, and specific consideration of selfregulation in the new media environment has led to recommendations that transparency and accountability be built into such systems ${ }^{3}$.

\footnotetext{
$\overline{2}$ For an explanation of the European and global tendencies toward self- and co-regulation in this sphere, see Lievens and Valcke, 2013.

${ }^{3}$ See for example the Manila Principles on Intermediary Liability (2015) and Article 19's Internet Intermediaries: Dilemma of liability (2013).
} 
The media is a specific area for regulation because fundamental rights are at stake, and there has always been tension around whether the incentives to protect rights to freedom of expression are better aligned with government or industry (Barnett, 2013: 353361). Andrew L. Shapiro argued already in 1995 that, "speech on the Net is subject to the whim of private censors who are not accountable to the First Amendment. Commercial on-line services... have their own codes of decency and monitors to enforce them" (1995: 59). Isabelle Rorive (2004: 26) later drew attention to the problem of "hidden censorship", followed by Damian Tambini, Danilo Leonardi, and Chris Marsden (2008: 282) who warned that systems of self-regulation and self-regulatory bodies imposing limits upon freedom of expression may amount to the "privatisation of censorship". Similar warnings against "putting subjective decisions in the hands of a corporate actor" without transparency or oversight were given in 2015 by the Committee to Protect Journalism (CPJ, 2015), a position also expressed by many freedom of speech organisations.

The concern stems from the fact that new gatekeepers can restrict content in ways that are very different to the gatekeeping actions of old media, and because of the increasing dominance of particular companies in the market (Moore, 2016). They can restrict how and what users share and access in order to enforce private rules, or in compliance with government requests and other legal requirements such as responding to court orders in civil cases (MacKinnon et al., 2014: 136). These decisions invest the new gatekeepers with a "regulatory" function and give their rules a "media law-like effect" (Jakubowitz, 2009), but without an editorial decision-making process or collectively established code. Their actions therefore raise fundamental questions about the control that new gatekeepers have over online expression: should the companies themselves decide what standards govern what is seen on the Internet.

\section{METHODOLOGY}

As one of the key social media with an important role as a path to news, Twitter is a relevant platform to examine in order to further understand what self-regulation means in the new context within which individual users and mass media (must) function in today's digital environment. Twitter is one of the most successful social media platforms, and is widely used particularly in Europe and North America. Twitter's gatekeeper position is not just significant in the distribution of news to users. It is also used by journalists to assess and represent public opinion (Anstead and O'loughlin, 2011, 2014) and as a source of information or location for finding what is newsworthy (Milosavljević, 2014; Broersma and Graham, 2013).

This study sought to answer two questions:

RQ1: What is the 'self-regulatory' framework of Twitter as a (new) gatekeeper regarding content?

RQ2: How has Twitter applied this framework? 
The investigation involved first a structured analysis of a selection of Twitter's documents from 1 January - 1 November, 2015 including: Terms of service(TOS), The Twitter Rules, Guidelines for law enforcement, and Policy and product updates aimed at combating abuse (Twitter, 2015a, 2015b, 2015c). The study also examined Twitter's responses to two specific cases: the case of James Foley, which involved the removal of content, and that of Milo Yiannopoulos, which involved the banning of a high profile individual user. Press releases, media reports and other articles from at the time of each event were used to reconstruct the details of the cases ${ }^{4}$.

\section{RESULTS OF ANALYSIS}

Twitter's policy documents were analysed against the factors for self-regulation described above, which include clear and measurable criteria, transparency and accountability to public, and the ability to appeal. Twitter's ToS define the procedures, behaviour and content that is allowed on the platform. The introduction to The Twitter Rules from 2015 states that the company "greatly value and respect our users' right to expression". At the same time, Twitter warns its users in the fourth paragraph of the ToS: "You understand that by using the Services, you may be exposed to Content that might be offensive, harmful, inaccurate or otherwise inappropriate, or in some cases, postings that have been mislabelled or are otherwise deceptive."

\section{Clear \& Measurable?}

Twitter includes in its ToS a list of prohibited types of content and activities. It reserves the right to restrict content from the platform that violates their terms of service and prohibit some content either in their terms of service or in guidelines like 'The Twitter Rules'. These standards or rules are constantly developing or changing, as Twitter explicitly warns a number of times. Besides the ToS and Twitter's Privacy Policy, 17 areas of general policies are listed in The Twitter User Agreement. Within these, only a few areas are related to political aspects of use and to freedom of expression in general.

Twitter does not allow pornography and "excessively violent media" in users' profile image, header image, or background image, as dictated in the Graphic content boundaries of The Twitter Rules. Pornography and photos of gunshot wounds are not illegal in the United States, where Twitter is headquartered, but the company has made the decision to exclude such content; however, no specific definition of "pornography" or "excessively violent media" is provided. This a key area of potential misuse when it comes to the content, including content from mass media that use Twitter for distribution, because the subjectivity involved can also lead to the blocking of content from other users, Twitter also bans "violence and threats". The Abusive Behaviour paragraph of The Twitter Rules (2016) states: "You may not publish or post direct, specific threats of violence against others." In addition, The Twitter Rules (2016) state: "You may not use our service for any unlawful purposes or in furtherance of illegal activities. International users agree to comply with all

\footnotetext{
$\overline{{ }^{4} \text { See list }}$ in appendix.
} 
local laws regarding online conduct and acceptable content". The 2016 Twitter Rules also ban harassment explaining that they consider:

If a primary purpose of the reported account is to harass or send abusive messages to others; if the reported behaviour is one-sided or includes threats; if the reported account is inciting others to harass another account; and if the reported account is sending harassing messages to an account from multiple accounts.

The terms used here as criteria are highly subjective, and the obligation to comply with local laws for an online platform used globally ads an additional layer of vagueness. Though a threat of violence against an individual may be relatively easy to identify, what constitutes "excessive violence" or "acceptable content" will vary greatly in different contexts.

\section{Transparent \& Accountable?}

While paragraph 5 of the ToS states that users own their content, it adds that the company

may modify or adapt your Content in order to transmit, display or distribute it over computer networks and in various media and/or make changes to your Content as are necessary to conform and adapt that Content to any requirements or limitations of any networks, devices, services or media.

The ToS states that Twitter may "remove or refuse to distribute any Content on the Services, to suspend or terminate users, and to reclaim usernames without liability to you." The process is anonymous, without clear identification of the personnel in charge of this process (unlike in traditional media where editors are named). The decisions are not publicised or explained. Twitter reserves the right to immediately terminate any account, without notice, if it deems that a user violates either the Rules or the ToS. Twitter personnel thus have no obligation to tell users when information has been removed, or why. The immediate termination of accounts without further notices is controversial when we consider the lack of clarity and subjective nature of terms and definitions mentioned above. Twitter's ToS states users are responsible for their use and content, and "for any consequences thereof", yet Twitter reserves the right to modify, adapt or block content as well as terminate accounts without outlining the process or even informing the user.

\section{Appeal?}

The legal basis for enforcement of the ToS in the US and Europe derives from contract and commercial law, as users agree to comply in exchange for a service, rather than from media law (MacKinnon et al., 2014: 20). As the user "agrees" to terms of service, Twitter decides what the user sees and expresses. The ToS includes no right to appeal Twitter's content decisions or the blocking of users. The only clause regarding disputes is \#12B, on Controlling Laws and Jurisdiction. The clause defines that the ToS and any action related thereto - including all claims, legal proceedings or litigation -are governed by the laws of the State of California and that disputes can only be resolved in the federal or state courts located in San Francisco County, California, US. To appeal against Twitter's enforcement of the ToS, users must be able to raise a court case in California. 


\section{The Case of James Foley and Twitter's reactions}

One of the most well-publicised cases of Twitter playing a gatekeeping role was its reaction to the execution of American photojournalist James Foley by ISIS in 2014 as distributed via Twitter with photographs and video. In a departure from established practice, Dick Costolo, the chief executive of the company, announced that any account retweeting the video would be closed, including the account distributing the video. Costolo announced via a Tweet just hours after the incident, "We have been and are actively suspending accounts as we discover them related to this graphic imagery." (Twitter, 2014)

However, Twitter applied different criteria regarding the distribution of Foley's photos to different actors. While individual persons had their accounts (temporarily) suspended if they distributed photos from the beheading, it was reported that Twitter did not suspend or react in the cases of accounts of media such as New York Post and New York Daily News. Twitter in a response to questions from Business Insider reporter Caroline Moss (2014, see Appendix) claimed that "'The Post's tweet contains this warning for some users, depending on their media settings', referring to a text block warning that shows up in place of the photo, allowing users the option to click through to the image or to skip over it." But, before the image appeared on Twitter timelines of both editors and journalists at these publications reporting on the story, they were not warned of the graphic nature of the image and such was the case for many others. Business Insider asked Twitter "why some accounts tweeting similar images of James Foley were suspended but not others", and reported receiving no response to this question. The number of deleted or blocked accounts and tweets is not known, however Twitter responded the same day the incident occurred.

These selective actions, which are not defined in ToS or in Twitter Rules, were criticised heavily by journalists at the time. Writing in The Atlantic (2014), Gillmor defined Twitter's actions as "editing" and a challenge to its identification as a neutral platform. The Guardian's James Ball stated that after this case, the "façade" of being merely curator was "eroding", raising question regarding its self-regulation, arguing it was now necessary that, "its [Twitter's] criteria are clearly and openly stated in advance, and that they are consistently and evenly applied." His colleague on The Guardian Emily Bell (2016) similarly defined this move as "an open and clearly editorial decision", and stated that Costolo's action "sat uneasily with those who had mistakenly thought Twitter was a 'free' platform open to all."

For the first time, Twitter in the Foley case acknowledged it was a platform that exercises editorial judgment. Twitter's proactive approach in Foley case also reversed a long record of non-intervention. Media professionals at the time identified Twitter's actions as editorial, as selecting what content the public should see based on some criteria, but the intervention was arbitrary, criteria were not transparent, and there was discrimination among different types of users. 


\section{The case of Milo Yiannopoulos}

In July 2016, Milo Yiannopoulos, technology editor at conservative website Breitbart, was banned from Twitter after allegedly conducting online harassment of renowned actress Leslie Jones, without receiving a clear explanation of what that harassment was. After criticizing the Ghostbusters actress Leslie Jones, she blocked him on Twitter, which led to him tweeting to his 338,000 followers he has been "rejected by yet another black dude". Following his public dispute with Ms Jones, a number of Yiannopoulos' followers directed abusive tweets at the actor - although he denied telling his fans to attack her. The actress said in a Tweet that she would quit Twitter because of harassment. After she publicly asked Twitter to intervene, Twitter chief executive Jack Dorsey personally intervened and asked Jones with a tweet to contact him privately to discuss her concerns, according to a news report by Variety.com (2016, see Appendix).

Within 48 hours of this tweet, Milo Yiannopoulos was banned from Twitter. Twitter's representatives published a statement that "people should be able to express diverse opinions and beliefs on Twitter. But no one deserves to be subjected to targeted abuse online, and our rules prohibit inciting or engaging in the targeted abuse or harassment of others." In a statement, Twitter (2016) alluded to the abuse Leslie Jones faced, but didn't speak of Yiannopoulos directly:

Over the past 48 hours in particular, we've seen an uptick in the number of accounts violating these policies and have taken enforcement actions against these accounts, ranging from warnings that also require the deletion of Tweets violating our policies to permanent suspension.

According to a report by Breitbart, Twitter sent an email to Yiannopoulos reading,

your account has been permanently suspended for repeated violation of the Twitter rules, specifically our rules participating in or inciting targeted abuse of individuals. Given that you have previously received repeated warnings for similar violations, your account will not be restored.

The media reports and comments varied and emphasized different aspects of the story. A Washington Post report on the incident emphasized Twitter's policy and lack of clear responses in the Yiannopoulos case and for other users who are also permanently banned from Twitter but not informed which tweets of theirs lead to the ban or offered appeal. Media professionals both questioned Twitter's lack of transparency in terms of how this particular decision was made and the arbitrariness of the decision of Twitter's representatives to personally contact Leslie Jones. However, many also commented on freedom of expression, which was in some eyes silenced in this matter. Jack Dorsey commented during a conference call that "freedom of expression means little if we allow voices to be silenced because of fear of harassment if they speak up" (CNBC). 


\section{DISCUSSION}

Analysis of Twitter's ToS and other rules shows that these fall short of the kind of transparency, public accountability and due process for appeals that are important for successful, beneficial self-regulation. These represent commercial conditions of use rather that self-regulation of media based on criteria that have been determined collectively within an industry or profession.

In the case of James Foley the varied treatment among different users (individuals or mass media) supports claims there are trends of inconsistent policy and application of rules found in other social media cases (for more on systems of removal see Doshi, 2015). Internal decision-making processes appear arbitrary and inconsistent, without clear criteria. The terminology used in Twitter's terms are highly subjective and require judgements to be made as to what qualifies, and, as has been shown elsewhere (see Radsch, 2015, on the definition of terrorism), imprecisions in definitions can be problematic.

The Yiannopoulos case appears to be an example of an arbitrary decision-making process, but such decisions may be commercially motivated, as it would be detrimental to the platforms to lose many celebrities or other high profile users. Twitter publishes annual 'transparency reports', but these only contain information on content removals or user blockages made in response to formal government requests or court orders. Whereas press self-regulators usually publish all decisions and their rationale, neither Twitter's terms nor the companies behaviour in the two cases here indicate any publication practice.

Both cases and the analysis of the ToS indicate a lack of transparency and public accountability in the system and suggest a lack of consistency in the application. Returning to the expectations of self-regulation discussed above, there is no indication of public participation in the formation of standards and criteria, and those published are highly subjective rather than precise and measurable. There is no realistic possibility of appeal against decisions for the vast majority of users. Because of the global nature of the company's services, creative solutions might have to be found to offer users unable to file a case in a California court to appeal the decisions of Twitter staff, but it should not be impossible. What may be lacking is the alignment of incentives to work towards such since the global nature of the company and its services also undermine the potential for the government regulation as a fall back option Campbell (1999) argued was necessary.

\section{CONCLUSION}

This paper focused on Twitter as one of the largest gatekeepers within social media in European Union and U.S. of America. It found the company's rules and mechanisms for enforcement to bear little resemblance to the kind of self-regulation needed in (social) media industries. This study was of course limited, leaving out similar platforms in other regions and other types of online services, however it does highlight some of the 
problems with referring to such companies internal rules and decisions on content as 'selfregulation'. Despite some ongoing debate as to whether or not services such as Twitter are media, there are increasing calls for them to take action on hate speech, extremism, and other content issues that traditional media, and their self-regulatory bodies have been dealing with for decades. Although Twitter does not identify itself as a 'media company' and a legal discussion about these definitions is still going on, Twitter (and other social media) nevertheless perform a different role than some other new gatekeepers, such as e-mail providers and ISPs, or even from some old gatekeepers whose function was solely transmission, such as cable operators. Twitter and other social media are, unlike these other gatekeepers, involved in daily decisions regarding content removal, blocking, filtering, or even banning individual users. Twitter more resembles 'traditional' media for which the editing function, involving content selection and distribution, including deciding which voices get disseminated, is one of their defining characteristics.

Though there may be no realistic threat of government regulation to incentivise them, social media companies, including Twitter, are increasingly engaging in efforts that have potential to lead to self-regulation, due in part to pressure from transnational policy makers and civil society groups. The recently adopted European Code of Conduct for Countering Illegal Hate Speech Online, signed by Facebook, Microsoft, Twitter and YouTube in May 2016 is an example of this. In the Code, the signatories commit to making clear processes through which they can be notified of illegal hate speech and to the removal of content within 24 hours. This contains no commitment to having clear procedures for appeal or guidance as to react to the notifications received. It is unlike old editors or journalists' codes that contained collective judgements made by the profession, sometimes in consultation with public, for example not to include the names of rape victims, or how to treat grieving families. The Code so far was agreed by only a handful of big companies that are all are providing different types of services, and still decisions on content will not made by a collective body, but internally by each company.

The regulation of content on these social media is not the industry's self-regulation, but is still only each company's private arrangement with its users. This could better be described as solo-regulation, in which a single, but powerful company, provides a limited and one-sided set of rules without involvement of a collective industry body and enforces them itself without external arbitration or appeal. As such companies, acting as specific gatekeepers, grow, and more and more people rely upon them for information these private arrangements could pose a threat to freedom of expression and public discourse. At the same time, as the number of users reaches hundreds of millions or billions worldwide, the gatekeeping role and regulation (self or otherwise) of Twitter and other social media, becomes an issue that in its scope and potential impact is incomparable to that of traditional media. More systematic research is needed to analyse different social media gatekeepers in various environments, and it is vitally important that there be collaboration within the industry and with the users to develop a coherent, as well as fair and transparent, model of self-regulation for this new and diverse group of services. 


\section{References}

>Anstead, Nick and O'Loughlin, Ben (2014) Social Media Analysis and Public Opinion: The 2010 UK General Election. Journal of Computer-Mediated Communication 20 (2): 204-220.

>Anstead, Nick and O'Loughlin, Ben (2011) The Emerging Viewertariat and BBC Question Time: Television Debate and Real-Time Commenting Online. The international journal of press/politics 16 (4): 440-462. DOI: $10.1177 / 1940161211415519$.

>Article 19 (2013) Internet Intermediaries: Dilemma of Liability. https://www.article19.org/data/files/ Intermediaries_ENGLISH.pdf (15.06.2016).

$>$ Barnett, Steven (2013) Leveson Past, Present and Future: The Politics of Press Regulation. The Political Quarterly 84 (3): 353-361. DOI: 10.1111/j.1467-923X.2013.12033.x.

>Bell, Emily (2016) Who Owns the News Consumer: Social Media Platforms or Publishers? CJR. http:// www.cjr.org/tow_center/platforms_and_publishers_new_research_from_the_tow_center.php (18.08.2016).

>Broersma, Marcel and Graham, Todd (2013) Twitter as a News Source - How Dutch and British Newspapers Used Tweets in Their News Coverage, 2007-2011. Journalism Practice 7 (4): 446-464. >Campbell, Angela J. (1999) Self-Regulation and the Media. Federal Communications Law Journal 51 (3): 711-772.

$>$ Committee to Protect Journalists (2015) Balancing Act: Press Freedom At Risk as EU Struggles To Match Action With Values. https://www.cpj.org/reports/2015/09/press-freedom-at-risk-europe.php (14.09.2015).

>Diakopoulos, Nick and Zubiaga, Arkaitz (2014) Newsworthiness and Network Gatekeeping on Twitter: The Role of Social Deviance. Proc. International Conference on Weblogs and Social Media (ICWSM), June 2014.

>Doshi, Shreyas (2015) Policy and Product Updates Aimed at Combating Abuse. https://blog.twitter. com/2015/policy-and-product-updates-aimed-at-combating-abuse_(28.10.2015).

>Enli, Gunn Sara (2007) Gate-keeping in the New Media Age - a Case Study of the Selection of Text Messages in a Current Affairs Programme. The Public 14 (2): 47-62.

>Erhardt Graeff, Stempeck Matt and Zuckerman, Ethan (2014) The Battle for 'Trayvon Martin': Mapping a Media Controversy On- and Offline. First Monday. http://firstmonday.org/ojs/index.php/ $\mathrm{fm} /$ article/view/4947/3821 (15.06.2015).

$>$ Gans, Herbert J. (1979) Deciding What's News: A Study of CBS Evening News, NBC Nightly News, Newsweek, and Time. New York: Vintage Books.

>Gillmor, Dan (2014) The New Editors of the Internet. The Atlantic. http://www.theatlantic.com/ technology/archive/2014/08/the-new-editors-of-the-internet/378983/ (29.05.2015).

>Jakubowitz, Karol (2009) A New Notion of Media? - Media and Media-like Content and Activities on New Communication Services. http://www.coe.int/t/dghl/stan dardsetting/media/doc/New_ Notion_Media_en.pdf (14.06.2015).

>Karppinen, Kari (2013) Rethinking Media Pluralism. New York: Fordham University Press. DOI: 10.5422/fordham/9780823245123.001.0001.

>Labo, Sharif and Damian Tambini (2015) Ofcom Consultation - Implications for Google and Facebook? http://blogs.Ise.ac.uk/mediapolicyproject/2015/05/18/ofcom-consultation-implicationsfor-google-and-facebook/ (19.09.2015).

>Lafrance, Adrienne and Robinson Meyer (2014) A Eulogy for Twitter. The Atlantic. http://www. theatlantic.com/technology/archive/2014/04/a-eulogy-for-twitter/361339/ (30.05.2015).

>Latzer, Michael, Just, Natascha and Saurwein, Florian (2013) Self-and Co-regulation, pp 373-398

in Price, Monroe, Verhulst, Stefaan and Morgan, Libby (eds) Routledge Handbook of Media Law. London: Routledge. DOI: 10.4324/9780203074572.ch21 (edition 2012).

>Lees, Tim, Ralph, Sue and Brown, Jo Langham (2000) Is regulation Still an Option in a Digital Universe?. Luton: University of Luton Press.

>Lievens, Eva and Valcke, Peggy (2013) Regulatory Trends in a Social Media Context, pp. 557-580 in Price, Monroe, Verhulst, Stefaan and Morgan, Libby (eds) Routledge Handbook of Media Law. London: Routledge. DOI: 10.4324/9780203074572.ch30 (edition 2012). 
>Lippmann, Walter ([1937] 1950) The Good Society - An Inquiry into the Principles of. Boston: Little, Brown and company.

>Livingstone, Steven, Bennett, W. Lance and Tumbler, Howard (2003) Gatekeeping, Indexing, and Live-event News: Is Technology Altering the Construction of the News?. Political Communication 20 (4): 363-380. DOI: 10.1080/10584600390244121.

> Løkkegaard, Morten (2010) Report on Journalism and New Media: Creating a Public Sphere in Europe. Report to the Committee on Culture and Education, European Parliament. http://www.europarl. europa.eu/sides/getDoc.do?language=EN\&reference=A7-0223/2010 (30.04.2015).

$>$ MacKinnon, Rebecca, Hickok, Elonnai, Bar, Allon and Lim, Hae-in (2014) Fostering Freedom Online - The Role of Internet Intermediaries. Unesco series on Internet freedom. http://unesdoc.unesco.org/ images/0023/002311/231162e.pdf (10.04.2015).

>Manila Principles (2015) The Manila Principles on Intermediary Liability. https://www.

manilaprinciples.org/ (15.09.2015).

>Mansell, Robin (2014) Governing the Gatekeepers: Is Formal Regulation Needed? http://blogs.Ise. ac.uk/mediapolicyproject/2014/11/27/governing-the-gatekeepers-is-formal-regulation-needed/ (22.07.2015).

>McQuail, Denis (1994) Mass Communication Theory: An Introduction. London: Sage Publications. >Milosavljević, Marko (2014) Novičarski dejavniki in internetna družbena omrežja: objavne vrednosti tvitov pri poročanju o evropskih volitvah. Javnost - The Public 21 (4): 77-92.

$>$ Mitchell, Amy, Rosenstiel, Tom and Leah, Christian (2012) What Facebook and Twitter Mean for News. The State of the News Media 2012. http://stateofthemedia.org/2012/mobile-devices-andnews-consumption-some-good-signs-for-journalism/what-facebook-and-twitter-mean-for-news/ (26.09.2015).

>Moore, Martin (2016) Tech Giants and Civic Power. King's College London: Centre for the Study of Media, Communication and Power.

$>$ Radsch, Courtney C. (2015) Privatizing Censorship in Fight Against Extremism is Risk to Press Freedom. Committee to Protect Journalists. https://www.cpj.org/blog/2015/10/privatizing-censorship-infight-against-extremism-.php (24.10.2015).

>Ristow, Bill (2013) The New Gatekeepers: Controlling Information in the Internet Age. Center for International Media Assistance. http://cima.ned.org/sites/default/files/final_2.pdf (27.04.2015). $>$ Rorive, Isabelle (2004) Freedom of expression in the information society, in Integrated Project 1: Making Democratic Institutions Work. Strasbourg: Council Of Europe. http://www.coe.int/t/e/ integrated_projects/democracy/02_Activities/00_Declaration_on_Information_Society/ IP1(2004)49En_free_exp.asp)/ (24.11.2015).

>Schulz, Wolfgang (2008) Regulating Search Engines? On the Use of Self- and Co-regulation in the field of Internet Search, pp. 79-86 in Nikoltchev, Susanne (ed.) Searching for Audiovisual Content. Strasbourg: IRIS Special.

>Shapiro, Andrew L. (1995) Keeping On-Line Speech Free: Street Corners in Cyberspace, pp. 58-61 in Jensen, Carl and Project Censored (eds) Censored: The News That Didn't Make The News And Why. New York: Seven Stories.

>Shoemaker, Pamela, Eichholz, Martin, Kim, Eunyi and Wrigley, Brenda (2001) Individual and Routine Forces in Gatekeeping. Journalism and Mass Communication Quarterly 78 (2): 632-651. DOI: $10.1177 / 107769900107800202$.

>Tambini, Damian and Labo, Sharif (2016) Digital Intermediaries in the UK: Implications for News Plurality. info 18 (4): 33-58. DOI: 10.1108/info-12-2015-0056.

$>$ Tambini, Damian, Leonardi, Danilo and Marsden, Chris (2008) Codifying Cyberspace: Communications Self-regulation in the Age of Internet Convergence. London: Routledge.

>Tuchman, Gaye (1978) The News Net. Social Research 45 (2): 256-266.

$>$ Twitter (2014) Dick Costolo on Twitter. https://twitter.com/dickc/status/502005459067625473 (28.05.2015).

>Twitter (2015a) Terms of service. https://twitter.com/tos (28.05.2015). 
>Twitter (2015b) The Twitter Rules. https://support.twitter.com/articles/18311-the-twitter-rules (28.05.2015).

>Twitter (2015c) Guidelines for law enforcement. https://support.twitter.com/groups/56-policiesviolations/topics/238-report-a-violation/articles/41949-guidelines-for-law-enforcement\#11 (28.05.2015).

$>$ United Nations (2016) Report of the Special Rapporteur on the promotion and protection of the right to freedom of opinion and expression. https://documents-dds-ny.un.org/doc/UNDOC/GEN/ G16/095/12/PDF/G1609512.pdf?OpenElement (15.06.2016).

$>$ United Nations (2011) Report of the Special Rapporteur on the promotion and protection of the right to freedom of opinion and expression, Frank La Rue. http://www2.ohchr.org/english/bodies/ hrcouncil/docs/17session/A.HRC.17.27_en.pdf (15.06.2016).

$>$ United Nations Security Council Counter-Terrorism Committee (2015) High-Level Meeting Adopts Madrid Ministerial Declaration On Stemming The Flow Of Foreign Terrorist Fighters. http://www.un.org/ en/sc/ctc/news/2015-07-30_Spain_MinisterialMeeting_FTF.html (11.09.2015).

$>$ Vis, Farida (2013) Twitter As A Reporting Tool For Breaking News - Journalists tweeting the 2011 UK riots. Digital Journalism. http://www.tandfonline.com/doi/full/10.1080/2 1670811.2012.741316?src=recsys\#.Uzw1oKiSySo (20.06.2015).

>White, David M (1950) The "Gate Keeper": A Case Study in the Selection of News. Journalism Quarterly. http://www.aejmc.org/home/wp-content/uploads/2012/09/Journalism-Quarterly-1950White-383-90.pdf (27.05.2015).

\section{Appendix}

List of articles used for case study building

Publication / Date / Title / Link

>Business Insider / August 20 2014 / Twitter Won't Suspend NY Post And Daily News For Posting

Grisly James Foley Covers / http://www.businessinsider.com/ny-post-daily-news-posting-foleyphotos-2014-8

$>$ CNBC / July 27 2016 / Dorsey treats Twitter like 'private fiefdom', banned user Milo Yiannopoulos says /http://www.cnbc.com/2016/07/27/dorsey-treats-twitter-like-private-fiefdom-banned-user-miloyiannopoulos-says.html

>Economist / 2015 / Take a step forward: Netflix and online video / http://espresso.economist.com/e3 d47e0c2d5427c6529f507dcfabe816?fsrc=scn\%2Fesp\%2Ffb

>Financial Times / 22 $2^{\text {nd }}$ July 2016 / Twitter still struggling a year after Jack Dorsey came back. / http:// www.ft.com/cms/s/0/07810e3a-4ffc-11e6-8172-e39ecd3b86fc.html\#axzz4HfrxfySw

$>$ Fortune / November $9^{\text {th }} 2015$ / Facebook and the Media Have an Increasingly Landlord-Tenant Style Relationship / http://fortune.com/2015/11/09/facebook-media/

>Fortune / June $15^{\text {th }} 2015$ / One big problem with Facebook as a platform for news: It deletes things. I http://fortune.com/2015/06/15/facebook-news-censorship/

>Fortune / September 10 2014 / Airbnb's biggest disruption: America's laws / http://fortune. com/2014/09/10/airbnbs-biggest-disruption-americas-laws/

$>$ Mashable / August $20^{\text {th }} 2014$ / In Wake of James Foley Beheading Video, Journalists Rush to SelfCensor / http://mashable.com/2014/08/19/james-foley-video-journalists/

>New Yorker / August $21^{\text {st }} 2014$ / Should Twitter have taken down the James Foley Video? / http:// www.newyorker.com/news/news-desk/twitter-taken-james-foley-video? (15.05.2015).

$>$ New York Times / July $20^{\text {th }} 2016$ / Twitter Bars Milo Yiannopoulos in Wake of Leslie Jones's Reports of Abuse / http://www.nytimes.com/2016/07/20/technology/twitter-bars-milo-yiannopoulos-incrackdown-on-abusive-comments.html?_r=2

$>$ News.com.au / July 21 2016 / Milo Yiannopoulos banned from Twitter, which highlights double standards of the platform / http://www.news.com.au/technology/online/social/milo-yiannopoulosbanned-from-twitter-which-highlights-double-standards-of-the-platform/news-story/5245dd1c1c f06671f254d0fd9472ed11 
>NPR / August 26 2014 / Beheading Video Stirs Debate On Social Media Censorship. Interview with Robert Hernandez / http://www.npr.org/2014/08/26/343352103/beheading-video-stirs-debate-onsocial-media-censorship >The Atlantic / April 30 th2014 / A Eulogy for Twitter / http://www.theatlantic.com/technology/ archive/2014/04/a-eulogy-for-twitter/361339/

>The Guardian / August $21^{\text {st }} 2014$ / Twitter: from free speech champion to selective censor? / http:// www.theguardian.com/technology/2014/aug/21/twitter-free-speech-champion-selective-censor >The Guardian / November $23^{\text {rd }} 2014$ / What's the right relationship between technology companies and journalism? / http://www.theguardian.com/media/media-blog/2014/nov/23/silicon-valleycompanies-journalism-news (15.05.2015).

>The Guardian / October $12^{\text {th }} 2014$ / Can Twitter make money out of breaking news or is it a PR platform? / http://www.theguardian.com/media/media-blog/2014/oct/12/twitter-breaking-newspr-vivian-schiller $>$ The Huffington Post / August 20 2014 / New York Post Condemned For Outrageous James Foley Front Page / http://www.huffingtonpost.com/2014/08/20/new-york-post-james-foley-frontpage_n_5694299.html

>The Verge / July $20^{\text {th }} 2016$ / Why was Twitter so vague about banning Milo Yiannopoulos? / http:// www.theverge.com/2016/7/20/12237222/twitter-milo-yiannopoulos-ban-harassment-leslie-jonestransparency

>The Slate / $21^{\text {st }} 2014$ / Did Twitter and YouTube Make the Right Call in Suppressing Images of James Foley's Beheading? / http://www.slate.com/blogs/future_tense/2014/08/21/james_foley_ beheading_did_twitter_make_the_right_call_in_suppressing_the.html $>$ Variety.com / July $20^{\text {th }} 2016$ / Twitter Bans Breitbart Editor In Response to Leslie Jones Harassment / http://variety.com/2016/digital/news/twitter-leslie-jones-milo-yiannopoulos-1201818460/ $>$ Washington Post / November $3^{\text {rd }} 2015$ / Tweets are disappearing on Twitter. Why? / https://www. washingtonpost.com/news/the-intersect/wp/2015/10/30/a-guide-to-why-some-activists-believetheir-tweets-are-being-censored-in-the-u-s/?tid=sm_fb >Witness / September $18^{\text {th }} 2014$ / Images of Horror: Whose Rules and What Responsibilities? / http:// blog.witness.org/2014/09/sharing-images-horror-roles-responsibilities/ (29.05.2015).

>Yahoo Finance / March $12^{\text {th }} 2015$ / The Long, Slow Death of Cable Just Reached a Tipping Point. I http://finance.yahoo.com/news/long-slow-death-cable-just-152700220.html 


\section{ZABRANJIVANJE, BLOKIRANJE I OSNAŽIVANJE: TWITTEROVA SAMOSTALNA REGULACIJA IZRAŽAVANJA}

\section{Marko Milosavljević :: Sally Broughton Micova}

SAŽETAK Regulacija ili samoregulacija internetskih medija jedna je od ključnih dilema za suvremene digitalne medije i njihovu politiku djelovanja. To uključuje nove digitalno posredovane gatekeepere kao što su društveni mediji. Privatna pravila posrednika, poput "uvjeta korištenja“ i politike sadržaja, u velikoj mjeri definiraju njihovo funkcioniranje i mogu se smatrati samoregulativnim mehanizmom. Internetski se posrednici sve više pozivaju da se uključe u izradu pravila korištenja i donošenje odluka o sadržaju. U ovom radu autori se fokusiraju na Twitter kao na jedan od najvećih i najznačajnijih internetskih izvora vijesti. Uvjeti korištenja i ostali dokumenti Twittera analiziraju se kao alati samoregulacije i kao kontekst unutar kojeg individualni korisnici i masovni mediji funkcioniraju, odnosno moraju funkcionirati u suvremenom digitalnom okruženju. Autori također promatraju kako je Twitter primijenio taj samoregulativni okvir u dva važna slučaja.

KLJUČNE RIJEČI

GATEKEEPERI, DRUŠTVENI MEDIJI, SAMOREGULACIJA, SAMOREGULATIVNI OKVIR, DIGITALNI MEDIJI

Bilješka o autorima

Marko Milosavljević :: Sveučilište u Ljubljani, Fakultet društvenih znanosti, Slovenija :: marko.milosavljevic@fdv.uni-lj.si

Sally Broughton Micova :: Sveučilište East Anglia, School of Politics, Philosophy, Language and Communication Studies, UK :: s.broughton-micova@uea.ac.uk 